\title{
The Risk of Atherosclerotic Cardiovascular Disease among Hyperlipidaemia Patients and Appropriateness of Statin Therapy
}

\author{
Maharani F. Iskandar, Nurmainah Nurmainah, Ressi Susanti \\ Department of Pharmacy, Faculty of Medicine, Tanjungpura University, \\ Pontianak, West Kalimantan, Indonesia
}

\begin{abstract}
Patients with hyperlipidaemia is at increased risk of developing atherosclerotic cardiovascular disease (ASCVD). The use of appropriate statin therapy is important to obtain optimal health outcomes. However, there was limited information regarding the risk of ASCVD among Indonesian hyperlipidaemia population and the appropriateness of statin therapy given to these patients. This study aimed to assess the ASCVD risks among the patients and evaluate the use of statin therapy at hospitalized hyperlidaemia patients. This cross sectional study used medical records as data source. This study was conducted at one hospital in Pontianak, Indonesia during Januari-June 2017. We included 50 subjects. The 10-year risk of ASCVD was assessed using ASCVD pooled cohort risk assessment equation (PCRAE). The results showed that $66 \%$ of the included subjects had a relatively high risk of developing ASCVD. Subjects with high risk of ASCVD received inappropriate statin therapy. High intensity statin should be given to these patients. In conclusion, large proportion of the subjects were at high risk of developing ASCVD. Nevertheless, inappropriate statin therapy were given to these patients. Improvement in medication practice should be done to prevent complication and increase quality of health outcomes.
\end{abstract}

Keywords: ASCVD, dyslipidemia, statin

\section{Introduction}

Hyperlipidaemia is characterized by elevated concentrations of any or all lipids in the plasma. It is one of the risk factors of atherosclerotic cardiovascular disease (ASCVD), including coronary heart disease $(\mathrm{CHF})$, stroke, and peripheral arterial disease. It is one of the leading cause of death worldwide. ${ }^{1,2}$

American Heart Association (AHA) in 2013, recommended statin as the primary drug of choice for hyperlipidaemia patients. There are four groups that are most likely to obtain the benefits of using statin, including patients with ASCVD, patients with LDL $\geq 190 \mathrm{mg} /$ dl, patients with diabetes mellitus (40-75 years), with LDL level of 70-189 $\mathrm{mg} / \mathrm{dl}$, and

Corresponding author: Maharani F. Iskandar. Department of Pharmacy, Faculty of Medicine, Tanjungpura University, Pontianak, West Kalimantan, Indonesia. Email:maharani9583@gmail.com

Received: 31 March 2018. Revised: 11 April 2018. Published: 23 April 2018. 
patients without diabetes (40-75 years) with an estimated 10-year ASCVD risk $\geq 7.5 \% .^{3,4}$

Patients who have clinical evidence of ASCVD and patients with LDL $\geq 190 \mathrm{mg} /$ dl should be given high intensity statin. Patients with low risk of developing ASCVD should consume moderate intensity statin. A 10-year risk of ASCVD could be assessed periodically using ASCVD pooled cohort risk assessment equation (PCRAE). ${ }^{5}$

However, there was limited information regarding the risk of ASCVD among Indonesian hyperlipidaemia population and the appropriateness of statin therapy given to these patients. This study aimed to assess the ASCVD risks among the hospitalized hyperlipidaemia patients and evaluate the use of statin therapy.

\section{Methods}

This cross sectional study used medical records as data source. This study was conducted at one hospital in Pontianak, Indonesia during Januari-June 2017. The inclusion criteria were hospitalized-hyperlipidaemia patients, aged $>18$ years. We excluded patients with pre-existing cardiovascular disease. Informed consent was not required because this observational study did not change the intervention and outcome of the patients. From each medical record, we extracted data regarding demographic characteristics, diabetes status, smoking status, and various clinical outcomes, including total cholesterol, HDL cholesterol, LDL cholesterol, blood pressure, and whether or not patients receiving antihypertensive treatment (if systolic blood pressure $>120 \mathrm{mmHg}$ ).

The data obtained were assessed using PCRAE to estimate the 10-year risk of ASCVD among patients. Descriptive analysis was used to evaluate the data.

\section{Results dan Discussion}

We included 50 subjects who met the inclusion criteria. Characteristics of the subjects is presented in Table 1. Majority of the patients were female (62\%) and aged $>50$ years $(84 \%)$. Most patients $(70 \%)$ suffered from diabetes and about $62 \%$ did not have smoking habits.

In contrast to previous study, male have higher risk of having exceeded lipid level than female.Female have estrogen hormone that prevents lipid profile abnormalities. This protective nature will disappear after women experience menopause. Decreased estrogen levels lead to decreased LDL catabolism and hepatic HDL removal, which can lead to the risk of atherosclerosis. ${ }^{6}$

Age is one of the risk factors that play a role in the incidence of cardiovascular disease. The risk of mortality will increase with age. The aging process naturally causes the blood vessels to be more susceptible to atherosclerosis. Inflammatory cells, endothelial cells, and smooth muscle cells of the blood vessels in the elderly differ from that of younger adults. Aging causes changes in the cell proliferation, apoptotic processes, and DNA repairment. The layers of intima and vascular media in the aging process continue to experience remodeling due to increased collagen deposition and elastin degeneration, so that blood vessels lose their elasticity and become stiff. $^{7}$

Cholesterol levels affect the incidence of cardiovascular disease. Based on the results of this study, the percentage of hyperlipidemic patients (patients who had total cholesterol $>200 \mathrm{mg} / \mathrm{dl}$ ) was 94\%. High cholesterol levels can lead to increased free fatty acids, which can lead to damage to beta cells of the pancreas so that the risk of diabetes mellitus could increase. Previous study found that 
Table 1. Characteristics of participants

\begin{tabular}{|c|c|c|}
\hline \multirow{2}{*}{ Characteristics } & \multicolumn{2}{|c|}{$\mathrm{n}=\mathbf{5 0}$} \\
\hline & Number & Percentage $(\%)$ \\
\hline \multicolumn{3}{|l|}{ Sex } \\
\hline Male & 19 & 38 \\
\hline Female & 31 & 62 \\
\hline \multicolumn{3}{|l|}{ Age } \\
\hline $40-50$ years & 8 & 16 \\
\hline$>50$ years & 42 & 84 \\
\hline \multicolumn{3}{|l|}{ Cholesterol level } \\
\hline$<200 \mathrm{mg} / \mathrm{dL}$ & 3 & 6 \\
\hline$>200 \mathrm{mg} / \mathrm{dL}$ & 47 & 94 \\
\hline \multicolumn{3}{|l|}{ LDL level } \\
\hline$<100 \mathrm{mg} / \mathrm{dl}$ & 2 & 4 \\
\hline$>100 \mathrm{mg} / \mathrm{dl}$ & 48 & 96 \\
\hline \multicolumn{3}{|l|}{ HDL level } \\
\hline$<55 \mathrm{mg} / \mathrm{dl}$ & 28 & 56 \\
\hline$>55 \mathrm{mg} / \mathrm{dl}$ & 22 & 44 \\
\hline \multicolumn{3}{|l|}{ Diabetes mellitus } \\
\hline Yes & 35 & 70 \\
\hline No & 15 & 30 \\
\hline \multicolumn{3}{|c|}{ Consumed anti-hypertensive drugs } \\
\hline Yes & 21 & 42 \\
\hline No & 29 & 58 \\
\hline \multicolumn{3}{|l|}{ Blood pressure } \\
\hline$<130 \mathrm{mmHg}$ & 22 & 44 \\
\hline$>130 \mathrm{mmHg}$ & 28 & 56 \\
\hline \multicolumn{3}{|l|}{ Smoking status } \\
\hline Yes & 19 & 38 \\
\hline No & 31 & 62 \\
\hline
\end{tabular}

people who had high cholesterol levels were 13.45 times more likely to suffer from type 2 diabetes mellitus than people who have normal cholesterol levels. Diabetes mellitus is one of the risk factors that can cause atherosclerosis. ${ }^{8}$

LDL cholesterol levels play a major role in the incidence of cardiovascular disease. Based on the results of this study, $96 \%$ subjects had LDL level > $100 \mathrm{mg}$.dl. Increased levels of LDL cholesterol is a strong predictor of the risk of cardiovascular events. LDL in the body is used in the repairment of cell membrane and in the production of steroid hormone and bile salts, but if the amount of serum LDL is excessive, it could cause hypercholesterolemia which could result in atherosclerosis. ${ }^{9}$

Increase in HDL level is important for cardiovascular health. Based on the results of this study, half $(56 \%)$ of the patients had HDL value $<55 \mathrm{mg} / \mathrm{dl}$. Decreasing HDL cholesterol levels in the blood will increase the risk of atherosclerosis. Endothelium dysfunction caused by repeated or persistent exposure will cause injury to the artery 
Table 2. Assessment of statin therapy

\begin{tabular}{|c|c|c|c|}
\hline Patients group & $\begin{array}{l}\text { Recommended } \\
\text { Statin }\end{array}$ & $\begin{array}{c}\text { Statin } \\
\text { Prescibed }\end{array}$ & Information \\
\hline $\begin{array}{l}\text { Patients with class III hyperlipidae- } \\
\text { mia with ASCVD Risk }<7.5 \%\end{array}$ & $\begin{array}{l}\text { Moderate intensity } \\
\text { statin }\end{array}$ & $\begin{array}{l}\text { Simvastatin } 20 \mathrm{mg} / \\
\text { Atorvastatin } 20 \mathrm{mg}\end{array}$ & Appropriate \\
\hline $\begin{array}{l}\text { Patients with class III hyperlipidae- } \\
\text { mia with ASCVD Risk }>7.5 \% \text {. }\end{array}$ & High intensity statin & $\begin{array}{l}\text { Simvastatin } 20 \mathrm{mg} / \\
\text { Atorvastatin } 20 \mathrm{mg}\end{array}$ & Not appropriate \\
\hline $\begin{array}{l}\text { Patients with class IV hyperlipidae- } \\
\text { mia without diabetes with ASCVD } \\
\text { Risk }<7.5 \% \text {. }\end{array}$ & $\begin{array}{l}\text { Moderate intensity } \\
\text { statin }\end{array}$ & $\begin{array}{l}\text { Simvastatin } 20 \mathrm{mg} / \\
\text { Atorvastatin } 20 \mathrm{mg}\end{array}$ & Appropriate \\
\hline $\begin{array}{l}\text { Patients with class IV hyperlipidae- } \\
\text { mia without diabetes with ASCVD } \\
\text { Risk }>7.5 \% \text {. }\end{array}$ & High intensity statin & $\begin{array}{l}\text { Simvastatin } 20 \mathrm{mg} / \\
\text { Atorvastatin } 20 \mathrm{mg}\end{array}$ & Not appropriate \\
\hline
\end{tabular}

wall. ${ }^{10,11}$

We found that patients who were at high risk of developing ASCVD receive inappropriate statin treatment (Table 2). They should be given high-intensity statin which include atorvastatin $80 \mathrm{mg}$ or rosuvastatin $20-40 \mathrm{mg}$. Moderate intensity statin includes atorvastatin $10-20 \mathrm{mg}$, rosuvastatin $5-10 \mathrm{mg}$, simvastatin $20-40 \mathrm{mg}$, pravastatin $40-80 \mathrm{mg}$, lovastatin $40 \mathrm{mg}$, fluvastatin XL 80, and pitavastatin 2-4 mg. ${ }^{4}$

\section{Conclusion}

In conclusion, large proportion of the subjects were at high risk of developing ASCVD. Nevertheless, inappropriate statin therapy were given to these patients. Improvement in medication practice should be done to prevent complication and increase quality of health outcomes.

\section{Acknowledgements}

The author would like to thank all medical staff at Sultan Syarif Mohamad Alkadrie General Hospital, Pontianak and counselor at Tanjungpura University.

\section{Funding}

None.

\section{Conflicts of Interest}

None declared.

\section{References}

1. Nelson RH. Hyperlipidemia as a risk factor for cardiovascular disease. Primary care. 2013;40(1):195-211.

2. Schaefer JR. Unraveling hyperlipidemia type III (dysbetalipoproteinemia), slowly. European Journal of Human Genetics. 2009; 17(5):541-542.

3. American Heart Association. Practice guideline: ACC/AHA release updates guideline on the treatment of blood cholesterol to reduce ASCVD risk. American Family Physician Journal. 2014;15;90(4):260-265.

4. Last AR., Ference JD, Falleroni J. Pharmacologic treatment of hyperlipidemia. American Family Physician Journal. 2011;84:551-558.

5. Preiss D, Kristensen SL. The new pooled cohort equations risk calculator. Canadian Journal of Cardiology. 2015;31:613-619.

6. Maas AHEM, Appelman YEA. 
Gender differences in coronary heart disease. Netherlands Heart Journal. 2010;18(12):598-602.

7. Dhingra R, Vasan RS. Age as a cardiovascular risk factor. The Medical Clinics of North America. 2012;96(1):8791.

8. Berger S, Raman G, Vishwanathan R, et al. Dietary cholesterol and cardiovascular disease: a systematic review and metaanalysis. American Journal Clinical Nutrition. 2015;102:276-294.

9. Pang SJ, Jia SS, Man QQ, et al. Dietary cholesterol in the elderly chinese population: an analysis of CNHS 20102012. Nutrients. 2017;9(9):934.

10. Rader DJ, Hovingh GK. HDL and cardiovascular disease. The Lancet. 2014;384(9943):618-625.

11. Ofori EK, Intiful FD, Asante M, et al. Prevalence of cardiovascular disease risk factors among students of a tertiary institution in Ghana. Food Science \& Nutrition. 2018;6(2):381-387. 